\title{
Author Correction: Oscillations of Delta-like1 regulate the balance between differentiation and maintenance of muscle stem cells
}

Yao Zhang (D), Ines Lahmann, Katharina Baum (D), Hiromi Shimojo, Philippos Mourikis, Jana Wolf(D, Ryoichiro Kageyama \& Carmen Birchmeier (B)

Correction to: Nature Communications https://doi.org/10.1038/s41467-021-21631-4, published online 26 February 2021.

The original version of this Article omitted the following from the Acknowledgements:

This work was supported by a grant by the German Science Foundation, FOR 2841 to C.B.

This has now been corrected in both the PDF and HTML versions of the Article.

Published online: 15 March 2021

\begin{abstract}
(c) (i) Open Access This article is licensed under a Creative Commons Attribution 4.0 International License, which permits use, sharing, adaptation, distribution and reproduction in any medium or format, as long as you give appropriate credit to the original author(s) and the source, provide a link to the Creative Commons license, and indicate if changes were made. The images or other third party material in this article are included in the article's Creative Commons license, unless indicated otherwise in a credit line to the material. If material is not included in the article's Creative Commons license and your intended use is not permitted by statutory regulation or exceeds the permitted use, you will need to obtain permission directly from the copyright holder. To view a copy of this license, visit http://creativecommons.org/licenses/by/4.0/.
\end{abstract}

() The Author(s) 2021 